\title{
The Developmental Welfare State and Social Policy: Shifting From Basic to Universal Social Protection*
}

\author{
Jörg Michael Dostal**
}

\begin{abstract}
Most people would agree that developing countries should advance from basic, informal, and insecure welfare provision toward universal, formal, and secure welfare regimes. This article examines how analytical concepts of developmental statehood and developmental welfare statehood might be applied to this issue. In particular, how is it possible to combine economic and social development objectives in a mutually beneficial manner? The article reviews the history of both concepts and some of their shortcomings; examines policy features of developmental (welfare) statehood, focusing on the examples of South Korea and four other countries that have frequently been referred to as "East Asian welfare regimes"; and explores some policy options for developing countries seeking to expand their economic and social policy-making capabilities.
\end{abstract}

Keywords: developmental state, developmental welfare state, social security, East Asian welfare regime, Korea

\section{INTRODUCTION}

The current crisis of neoliberal globalization has made it possible for alternative development policy approaches to gain access to larger audiences and compete for

\footnotetext{
* An earlier version of this paper was presented at the First Annual Korean-American Public Management Conference "New Research Directions for Globalized Public Management", co-organized by the Graduate School of Public Administration, Seoul National University, and the Graduate School of Public and International Affairs, University of Pittsburgh, Pittsburgh, November 12, 2010. The author is grateful for comments received from Larissa Douglass, Sangook Park, and three anonymous reviewers.

** Jörg Michael Dostal is Assistant Professor in the Graduate School of Public Administration, Seoul National University, Korea. His research interests include comparative politics, global social policy, and the role of knowledge and expertise in the policy process. E-mail: jmdostal@snu.ac.kr.
}

Manuscript received October 10, 2010; out for review October 23, 2010; review completed December 6, 2010; accepted December 13, 2010.

The Korean Journal of Policy Studies, Vol. 25, No. 3 (2010), pp. 147-172.

(C) 2010 by the GSPA, Seoul National University 
public endorsement. In this context, one of the main debates concerns the question of how to combine successful economic development with rising levels of social protection. Since the 1980s, the field of development policy has been dominated by neoliberal policy prescriptions. They have focused on approaches such as the New Public Management to promote market principles in the governance of the public sector or the direct privatization of public-sector entities. Other neoliberal policies have included the downscaling of state intervention in the economy, financial market deregulation, efforts to attract rising levels of foreign direct investment, and multilateral trade liberalization under the World Trade Organization. In addition, policy-making was supposed to be based on the contracting out of formerly public services to the private sector, decentralization of decision-making, and good governance (UNRISD 2010, 257-58).

Over the last 30 years or so, these policies were principally advanced by international financial institutions such as the World Bank and the International Monetary Fund (IMF). The neoliberal approach to social policy-making in developed and developing countries alike-as with earlier liberal and "residual" concepts of welfare in general-has always been based on limited state intervention, orientation to market outcomes, and the expectation that growth will in the long run be shared by an increasing number of citizens thereby benefiting the poor.

However, such neoliberal accounts of social development have been subject to devastating criticism. Mainstream claims about a decline of extreme poverty since the 1990s due to market-oriented reforms across the world—deriving from the World Bank, and sometimes uncritically accepted even by institutions that are otherwise critical of the World Bank (UNRISD 2010, 1) — have been challenged as based on erroneous measurements and an inappropriate conceptualization of what constitutes poverty (Kiely 2007, 415-20). Moreover, the World Bank data, even if accepted, suggests that progress in poverty reduction is mostly due to economic growth in the People's Republic of China and, to a lesser extent, India. If these countries are taken out of the equation, there has been no clear decline in poverty rates since the 1990s (Parsons 2008).

Alternative development theorists working outside of the World Bank and IMFendorsed mainstream have therefore stressed the importance of state agency and state capabilities in the process of development. They have argued that the state must provide leadership in the transition to an industry- and information-based economy, that markets require for their survival conditions that cannot be provided by the marketplace itself, and that the answer to the structural needs of the economic transition is the formation of developmental states with expanded state agency and activity. A core feature of the proposed developmental state is social protection to help society deal with the social costs of transition and to avoid a breakdown in public order. This has been described as a "protective counter movement" and as an effort to combine eco- 
nomic and social progress (Polanyi 1967 [1944]; Riesco and Draibe 2009). ${ }^{1}$

This article focuses on accounts of social development that stress the crucial role of the developmental state. An effort is made to apply the concept to debates about economic and social development; the comparative study of welfare state regimes; and the analysis of the relative merit of basic and universalist social policies.

The subsequent discussion falls into three main sections. Section one discusses concepts of the developmental state; section two outlines the more recent idea of the developmental welfare state and its analytical link to debates about international welfare state regimes; and section three examines how welfare policies in developing countries might be expanded by analyzing the basic social security approach, on the one hand, and accounts of transformative and universalist welfare policies, on the other. Frequent reference is made to the experience of East Asian countries, especially Korea, even so the lessons drawn from them are necessarily limited geographically and historically.

\section{THE DEVELOPMENTAL STATE}

The concept of the developmental state can be approached from a variety of perspectives and at different levels of analysis. First, one can understand it to be the rule rather than the exception in the process of transition from traditional to industrial societies in the nineteenth and twentieth centuries. It can be argued that practically all industrializing nations, including Britain until the 1840s, attempted to guide investment in a strategic manner. At the same time, domestic industries were protected from external competition through tariffs, industrial quotas, and similar efforts (H.-J. Chang

1. Just as in the case of neoliberal approaches, calls for a developmental state might be criticized for focusing on a narrow and instrumentalist understanding of social welfare as a tool for development rather than as a normative goal in its own right. For example, theorists of new concepts of welfare have stressed that traditional welfare states focused too narrowly on issues such as health, unemployment, and pensions, and usually failed to take account of emerging social risks such as environmental degradation, decline in the quality of the urban infrastructure, and threats to psychological well-being and social integration (Aspalter 2007).

2. H.-J. Chang (2009) pointed out that, until World War I, only the Netherlands and Switzerland could be described as consistently following free trade principles without long periods of tariff protection for domestic industries. They made up for this by ignoring copyright laws and freely copying from their competitors. During the twentieth century, Sweden also had fairly low overall tariffs. However, this was due to geopolitical factors that allowed for an exceptionally open version of the developmental state. 
2009, 8-9, 12). ${ }^{2}$ Thus, countries such as the United States, Germany, and France constructed developmental states in the nineteenth century, although the concept varied from one country and time period to the next. By way of analogy, one might apply an argument that was put forward in the context of analyzing twentieth-century socialist states, arguably another species of developmental state, as equally valid for developmental states in general:

No ... country was "typical"; each had its specificities, and each shared certain features with some but not all other countries of the bloc. To assume that conclusions drawn from one will apply to all would be unwise, but material from any of them can nevertheless raise questions that might prove fruitful elsewhere. (Verdery 1996, 11)

There are trade-offs between a minimalist definition of what turns a state into a developmental state and its analytical usefulness. For example, if one accepts a minimalist definition of the developmental state as one that performs a "strategic role in economic development, with a bureaucracy that is given sufficient scope to take initiatives and operate effectively" (Kwon 2005, 483), one might find that, analytically, another list of tasks is required that such a state has to successfully perform in order to fulfill the developmental mission.

This also raises the question of whether or not a state ceases to be a developmental state after the transition is complete (Dore 2000, 212; Dore 2007, 4-7). Do states remain developmental in character even after the transition period by, for example, adopting features of a social democratic, neocorporatist, or elite bureaucracy model (for example, the Swedish, West German, and Japanese cases at different points in history)?

Another problem with a minimalist definition of the developmental state is that authors have stressed the primacy of the state bureaucracy and of economic development above all other actors and missions. In this context, a cluster of five East Asian states-Japan as a model emulated to various degrees by Korea, Taiwan, and less strongly by Singapore and Hong Kong - is held to define the more recent application of the "capitalist developmental state" (Johnson 1982):

A state attempting to match the economic achievement of Japan must adopt the same priorities as Japan. It must first of all be a developmental state—and only then a regulatory state, a welfare state, an equality state, or whatever other kind of functional state a society may wish to adopt (Johnson 1982, 306).

Johnson's concept has been influential far beyond its original application to the Japanese case. Yet despite the original concept's emphasis on the primacy of economic 
development objectives over welfare objectives, other authors have linked Johnson's ideas with the debate on welfare regimes deriving from Esping-Anderson's (1990) effort to provide ideal-type regime classifications. The latter identified three types of welfare capitalism: (1) social democracy (the Scandinavian countries); (2) conservatism/Christian democracy (many continental European countries); and (3) liberalism (the United States, United Kingdom, and Ireland).

Another author suggested that a fourth regime type should be added, East Asian "productivist welfare capitalism" (Holliday 2000, 709), characterized by a narrow focus on welfare for core workers in the service of economic growth objectives, leaving other welfare provisions to the family as the residual unit. It addition, it has been stressed that Johnson's focus on state authority is not sufficient to deliver successful economic development. Other crucial factors for the success of the developmental state in East Asia have included state autonomy from society; elite consensus on developmentalism; state capability to deliver policy outcomes in an effective manner (something that might be lacking in states that are both authoritarian and weak); and, last but not least, world-market-conforming industrial policies (Wu 2007, 980).

\section{The East Asian Experience}

One shared feature of some East Asian developmental states was that they used geopolitical and geoeconomic opportunities granted by stronger and more developed states (primarily the United States during the Cold War) to protect their home markets, develop competitive industries behind tariff walls, and later engage in export-oriented economic policies. ${ }^{3}$ Yet the policy instruments used in this context, and the industrial structures that developed over time, were different from country to country. The open city-states of Hong Kong and Singapore differed fundamentally from Korea and Taiwan. The former allowed foreign direct investment early on, while the latter, especial-

3. In order to describe the dependent relationship of, for example, Korea and Taiwan with the United States during the Cold War, one could perhaps apply the term "associated-dependent development," which was coined in 1973 by Brazilian sociologist Fernando H. Cardoso (Cypher and Dietz 2009, 192-93). However, Cardoso focused in his analysis on the then alliance of Latin American authoritarian states with transnational corporations, in which only very limited transfer of technology between the center and the periphery occurred. The Korean case was different in that transnational corporations were largely excluded from the domestic market. One might say that Korea and, to a lesser extent, Taiwan followed a niche strategy that was possible because the United States allowed unusually generous access to its market without reciprocity and accepted technology transfer to a much larger extent than had been the case in Latin America. 
ly Korea, largely closed the domestic economy to foreign direct investment (Timmer and van Ark 2000, 15-20). On the other hand, both countries received bilateral loans, mostly from the United States, that accounted in the 1960s and early 1970s for a large share of gross domestic investment.

Even the two otherwise most similar countries, Korea and Taiwan, developed very different economic structures. Korea's was based on large, vertically integrated chaebols ${ }^{4}$ and the production of finished industrial goods, and Taiwan's on the creation of a loosely organized network of small and medium-size companies producing intermediate goods for export based on flexible adaptation to external demands (Shin and Chang 2003, ch. 2; Hamilton and Cheng-Shu 2008, 104-5, 126-30).

Another important topic in the literature on the developmental state has been the discourse of international organizations such as the IMF and the World Bank. In the post-World War II period, two major international policy trends could be observed, namely import-substituting industrialization (the dominant approach in many countries from the 1950s to the 1970s) and export-led development (the dominant approach from the 1970s onward). In this context, surveys of the World Bank's policy advice demonstrate that the Bank's discourse went full circle. Initially, heavy emphasis was placed on state capabilities in macroeconomic management, but this was later shifted toward a primary concern with microeconomics and efforts to "get the prices right."

The latter approach argued that state intervention in the economy resulted in poor resource allocation and low growth rates. However, subsequent neoliberal policies to rejuvenate growth rates in Africa and Latin America, as advised by the World Bank and the IMF since the 1980s — such as structural adjustment programs, privatization, and expansion of regulatory policies to supervise the newly privatized sectors of the economy-did not achieve lasting success in developing countries, something that is by now also acknowledged by senior World Bank authors (Yusuf 2009, 23-29).

The most successful development policy outcomes in East Asia were observed to be due to these countries' insistence on establishing their economic policies without much attention to advice from institutions such as the World Bank. Instead, these countries focused on building up, maintaining, and expanding the capabilities of their developmental states. In Korea, for example, the developmental state was established in the 1960s, and the subsequent shift from import substitution to export-led development took place in a context of institutional continuity (Cumings 2005, 222-23). ${ }^{5}$

4. The Korean term chaebol is usually translated as "family-owned industrial conglomerate."

5. Some of the groundwork had already been laid for the construction of a developmental state in Korea during the Japanese colonial era (1910-1945). "The chief feature of the governmentbusiness relationship in colonial Korea was the overwhelming dominance of the state. The 
It has been said that the Korean developmental state went further than the earlier Japanese example by nationalizing commercial banks, thereby "totally [subordinating] their lending decisions to industrial policy" and establishing the long-standing "statebanks-chaebol nexus" that became "the central feature of the Korean economic system" (Shin and Chang 2003, 13). ${ }^{6}$ The growth policy objectives of the developmental state were maintained while policy tools were used in a flexible manner.

External and Korean observers alike have stressed that earlier experiences with import substitution were a precondition for later success in export-led development (Hamilton 1986, 43-45; Kim, Moon, and Lim 2009, 19). Some features of the earlier model were maintained, such as providing state guidance on private company investment strategies in exchange for guarantees in domestic market share, or establishing native "technology quotas" in export goods in order to build up domestic technology capabilities (Kim, Moon, and Lim 2009, 25-26).

Continuities in the functioning of the developmental state could be observed even when financial market and trade liberalization started to dominate the picture after the East Asian economic crisis of 1997. It was the existence of the developmental state that provided the institutional framework for the successful capture of external markets at a later point—without it, there would have been no successful engagement with trade liberalization. ${ }^{7}$

[Japanese] Government-General determined the basic direction and priorities of economic development through the establishment of official industrial policy and ensured, in large part through its control of the colonial financial structure, that its plan would be carried out in the private sector" (Eckert 1991, 125).

6. This description is broadly accepted in the literature. One author who has otherwise criticized the concept of the developmental state as a "mystification process" nevertheless accepted that the post-1961 Park regime did exercise control over individual capitalists, thereby "creating the image of a state independent from the dominant class" (D.-o. Chang $2009,66,70)$. This was a crucial difference from the earlier Rhee regime, which was based on direct clientelism. Yet the Rhee regime's land reform in the early 1950s did create one of the favorable preconditions for the construction of the developmental state after 1961 (Hwang 1994, 118-25).

7. This has now also been acknowledged by World Bank authors such as Yusuf $(2009,32)$, who stressed that "only the state could do the job of carpentering them [market institutions]." In addition, many policy tools of the developmental state, such as sector-wide coordination of investment in research and development and long-term planning of technological innovation based on state-provided basic research, are also characteristics of many other advanced industrial countries belonging to the group of coordinated market economies. 


\section{THE DEVELOPMENTAL WELFARE STATE}

The concept of the developmental welfare state is less established than that of the developmental state, and the relationship between the two is often unclear. The concept of the developmental state as advanced by Johnson $(1982,1999)$ stressed the absolute dominance of economic development over all other policy goals. Thus, developmental states are in the beginning characterized by fragmented and selective welfare policies that closely follow growth objectives, such as providing social security for core state employees and some categories of workers in strategic sectors of the economy. These selective formal welfare policies coexist with informal welfare efforts in the society undergoing modernization. Developmental states are therefore not yet developmental welfare states, but the trajectory of modernization suggests that they will move in this direction eventually.

The first historical experience with a developmental welfare state was Bismarck's introduction of social insurance legislation for different categories of workers in Germany after 1883 . This move was subsequently copied in other European and nonEuropean countries. Observers suggested that such policies were advanced to stabilize capitalism economically and politically, contribute to nation-building, and help strengthen national security (Kwon, Mkandawire, and Palme 2009, 1). As workers became dependent for their social security on the state, they were incorporated into an economic and political regime that, in the case of Bismarck's Germany, was authoritarian and socially reformist at the same time.

The transformation of developmental states into developmental welfare states had a large variety of outcomes. What the 1880 s Bismarckian welfare state and the postWorld War II East Asian developmental welfare state shared was the selective character of social insurance and the clear preference to provide social protection for core groups rather than to engage in redistributive efforts (Park and Jung 2009, 71-72). There were, however, variations in the role of the state, since the Bismarckian system placed more emphasis on direct state involvement in administering social insurance schemes - thereby replacing earlier union- and church-based schemes-while the East Asian states focused on regulation rather than direct control.

The original East Asian models had a cultural bias against direct welfare state expansion in favor of state cooperation with employers, civil society, and the family, which was regarded as the welfare-providing institution of last resort (Aspalter 2006, 298). This early bias against state-provided welfare was partially overcome in Korea and Taiwan after the 1987 democratic transitions in both countries. Democratization created openings for welfare state advocates to demand the introduction of more universalist provisions based on citizenship rather than social status or group membership 


\section{(Peng 2004).}

From a historical perspective, it has been suggested that success or failure of the developmental welfare state — as with the developmental state in general-depends on a favorable domestic and geopolitical environment. In principle, developmental welfare states could be either democratic and inclusive or authoritarian and exclusive. In this context, three main historical outcomes have been observed: (1) successful establishment of state autonomy from vested interests, due to the absence of powerful social classes that could retain veto powers, such as landowners and multinational companies; (2) failure to establish state autonomy when such veto powers are too strong; and (3) the special cases of the Scandinavian countries, in particular Sweden. There, the need for state autonomy was replaced by the construction of a political coalition of social democrats, unions, and agricultural interests, which allowed for innovative developmental welfare state building based on an alliance that could link the state and civil society (Kwon, Mkandawire, and Palme 2009, 6, 9; Blyth 2002, ch. 4).

\section{Welfare Regime Typology}

The notion of the developmental welfare state is a theoretical construct that aims to capture the link between economic growth strategies and efforts to use social policy as an effective tool in this context (Kwon 2005, 479). The concept should be understood as dynamic in offering policy lessons that might be applicable in a large variety of countries and welfare regimes at different times. For example, it has been argued that the developmental welfare state might be able to overcome limitations of the earlier developmental state, such as authoritarianism and an instrumental understanding of social policies, by shifting from selective to inclusive welfare development, thereby combining key principles such as productivism, universal social investment, and democratic governance (Kwon 2005, 482).

The advocates of this concept argue that it is of potentially global relevance-or at least of relevance for those developing countries aspiring to catch up with advanced OECD (Organisation for Economic Co-operation and Development) countries. Holliday (2000) presented the concept of East Asian "productivist welfare states" as a fourth welfare regime type along the lines of the three types Esping-Anderson (1990) presented earlier (social democracy, conservatism/Christian democracy, and liberalism), but advocates of the "developmental welfare state" concept argue that it goes beyond that more modest approach.

Critics of the concept suggest, however, that the developmental welfare state in East Asia can be analyzed in the context of existing accounts of welfare state development. They hold that the developmental shift from exclusive to inclusive welfare poli- 
cies observed in East Asia-especially in Korea and Taiwan — did also occur in earlier cases of welfare state expansion and should therefore be understood as part of a general developmental pattern (Kim 2008, 111). In addition, it has been suggested that it is time to move away from focusing on state agency and put more analytical emphasis on civil society actors such as a "cross-class [pro-]welfare alliance" (Kim 2008, 118).

Thus, in order to clarify and advance the concept of the developmental welfare state, two issues require further analysis. First, the question of whether it is merely a fourth regime must be discussed in more detail, in order to explain what is exceptional about East Asia and what might have more universal significance. Second, the relationship between the developmental state and the developmental welfare state must be clarified. How do changes in the structure of the developmental state affect welfare policies? These questions can be viewed from both a qualitative and quantitative perspective.

The qualitative analysis of East Asian welfare states as a fourth regime derived from the observation that neither existing classifications from other continents (such as the European notion of conservative welfare regimes) nor the assumption of a single shared model of East Asian welfare were appropriate. Instead, observers suggested that some East Asian states shared certain characteristics that were absent in European or other OECD countries. In particular, the politics of class in some East Asian countries was held to be driven by the middle class and based on relatively egalitarian income distribution, an ideology of social and economic modernization rather than a paternalistic or Christian ideology, and a less comprehensive system of welfare provision than that of the conservative welfare states of continental Europe (Lee and $\mathrm{Ku}$ 2007, 199).

However, these are very general characteristics that do not yet provide for a clearly defined fourth regime. Some observers were therefore inclined to classify countries such as Japan and Taiwan as conservative, in line with Esping-Anderson's typology, rather than as part of a separate group of East Asian welfare states. In addition, the long history of transcontinental policy learning demonstrated that Japan, as the first East Asian model, had emulated welfare policies from European countries since the nineteenth century (Kasza 2002). ${ }^{8}$

Other critics focused on the analytical difference between welfare regimes and welfare state regimes. Instead of depending on state agency, welfare rights and entitle-

8. The same observer also argued against the notion of internal consistency of welfare regimes and suggested that most countries were characterized by "disjointed set[s] of welfare policies." Thus, one should expect a tendency for regime logics to decline over time due to overlapping and contradictory policy initiatives deriving from a large numbers of actors (Kasza 2002, 271). 
ments might be found in informal domains such as social (and often clientelist) relationships and cultural expectations. These critics further suggested that the rise of welfare state regimes was only possible through a process of "de-clientelization" that replaced informal social security with state-provided and formal welfare provisions (Wood and Gough 2006).

In summary, the qualitative discussion casts doubt on the analytical coherence of welfare state regimes. This is certainly significant at the level of discourse and deliberation about welfare policies in most OECD countries, in which one could observe increasing overlap between different regime types. ${ }^{9}$

Quantitative evaluation focused on the analysis of data on levels of regime-specific welfare expenditure along the lines of Esping-Anderson's welfare state typology. In this context, the welfare typologies remain analytically useful when applied in the comparative analysis of welfare state effort. ${ }^{10}$ For example, recent research based on cluster analysis of cross-country expenditure data produced broadly similar results for a group consisting of Japan, Korea, and Taiwan (Lee and Ku 2007; Park and Jung 2009). Most notably, the Japanese case shared similarities with other liberal and conservative regimes in the OECD as much as it did with Korea and Taiwan, and is therefore located in between liberal, conservative, and East Asian regimes (Lee and $\mathrm{Ku}$ 2007). Thus, only Korea and Taiwan form a distinct East Asian welfare regime. (The city states of Hong Kong and Singapore form another cluster that is characterized by less inclusive and more fragmented provisions. In the latter two cases, provident funds rather than social insurance have been the most common form of welfare provision, due to their shared British colonial past.)

In conclusion, granting Korea and Taiwan the status of a fourth or East Asian welfare state regime is plausible due to their similar political and economic trajectories (UNRISD 2010, 260; Wade 1990, 108, 307). ${ }^{11}$ It might be argued, however, that they

9. In particular, neoliberal ideas have been influential in each of Esping-Anderson's three welfare state regimes, and recalibration and retrenchment of entitlement programs in fields such as health, pensions, and unemployment insurance have become central political concerns in mature welfare states (Brütt 2010).

10. Esping-Anderson's account of "three worlds" of welfare capitalism (1990), based on the norms and values of social democracy, conservatism/Christian democracy, and liberalism, still explains levels of OECD welfare state effort despite recent shifts in the field of discourse and ideas in which, before 2008, neoliberalism had gained some degree of dominance.

11. In addition to their shared experience of Japanese colonialism, Korea and Taiwan both engaged in land reform in the 1950s and created developmental states based on strategic co-option of some sections of the population through targeted welfare policies. Both states 
do not represent a fundamentally new regime but that their progression from targeted and fragmented welfare provisions to more generous and comprehensive systems can be understood as the rule rather than the exception in comparison with earlier cases of welfare state expansion. Long periods of high economic growth and successful democratization in both countries after 1987 helped to create momentum, while certain advantages of late-developing countries, such as a demographic profile weighted toward young people, also created supportive conditions (Kwon, Dong, and Moon 2010). The two countries certainly stood out for their expansionary policies at a time when most OECD countries were implementing welfare recalibration and retrenchment.

Finally, while one might identify an East Asian welfare model consisting of Korea and Taiwan (which would cover only a small part of East Asia), the same does not apply to the concept of a shared Asian welfare state. Here, levels of economic development, external geopolitical links, and the distinctive geographic and demographic trends of Asian countries suggest that a single shared Asian welfare model does not exist and should not be expected in the future (Kasza 2006, 127).

\section{Two Challenges to the Developmental Welfare State}

The concept of the developmental welfare state remains contested, and at least two alternative accounts have been put forward to challenge some of its basic assumptions. The first challenge derived from the perspective of modernization theory, stressing similarities between the cases of Japan, Korea, and Taiwan and western welfare state trajectories. These accounts suggest that, once a certain GDP per capita has been reached, international policy diffusion and some degree of regime convergence should be expected as far as the basic parameters and institutions of the welfare state are concerned. The second challenge focused on whether or not the original concept of developmental statehood for Korea and Taiwan was still analytically useful. Critics suggested "normalization" of state agency in shifting away from the earlier command role and toward the more limited role of policy-making moderator.

As far as Korea is concerned, the critics stressed that the developmental state was

enjoyed sustained US assistance during the Cold War and borrowed extensively from Japanese and other economic policy models. However, the opportunity to expand welfare policies in the direction of universalism occurred after democratization in 1987, when health, unemployment, and pension policies were shifted toward near-universalism, with Taiwan trailing Korea by a few years (NPF 2009). Furthermore, it has been argued that the experience of the two countries confirms that economic success is a precondition for welfare state expansion; this is in line with the earlier Japanese experience beginning in the 1960s, which in turn replicated earlier Western models (Kasza 2006, 13, 124). 
largely dismantled in two stages. After democratization in 1987, the state lost much of its political autonomy in its interaction with capital and labor. Next, the Asian financial crisis of 1997-1998 removed many of the remaining governmental steering powers in the economic field. Thus, the chaebols gained increasing autonomy from state control and, at the same time, class conflict became politicized, allowing for a more independent political representation of working- and middle-class interests.

As a result, Korea experienced a dual transition from authoritarianism to democratization and from comprehensive to limited economic management, thereby changing from a "comprehensive to a limited developmental state" (Kim 1993, 229). Changessuch as the reorganization of the financial sector, trade liberalization, liberalization of domestic equity and bond markets, and reform of corporate sector and labor markets to decrease government intervention and increase flexibility-affected all spheres of the economic system (D.-o. Chang 2009, 136-37). Significantly, after 1997 the Korean government's discourse turned against what had earlier been the very basis of the Korean model. President Kim Dae-jung used his inauguration speech in February 1998 to criticize "a collusive link between politics and business" and "governmentdirected banking practices." Subsequently, the Kim government demanded "clear and transparent regulations for the imposition of market principles among creditor financial institutions" (MSF 2001).

Without analyzing the restructuring of Korean state-capital-labor relations any further, it can be concluded that the older discourse of developmental statehood has been abandoned. However, this is not to say that the new, more liberal discourse represents a complete change of the trajectory of the Korean economic model. For example, rather than losing their significance, the chaebols have shifted since 1999, in what has been referred to as the Korean globalization years, toward large-scale foreign direct investment of their own in an effort to capture market share in China, Japan, Indonesia, and other countries (Valli 2010).

Thus, one could understand Korea's parallel setting up of an inclusive developmental welfare state in the late 1990s in response to the Asian financial crisis, which followed the more spontaneous push for higher wages after democratization in 1987, as a transformation rather than a dissolution of the earlier model. In expanding welfare policies, the state created the preconditions for a successful shift from extensive to intensive economic growth and accommodated sections of labor and the middle class. In Korea, the globalization years, at least before the 2008 global economic crisis, were characterized by growth rates that were nearly as high as in the 1980s and 1990s, pointing to new sources of economic dynamism and demonstrating that developmental welfare contributed to successful modernization.

Whether or not the term "developmental welfare" remains appropriate in the years 
to come, or whether new concepts such as "social quality" or "social investment" should be employed to describe this transformation in statehood, is an open question. Indeed, any further extension of welfare policies would be a success, given that the Korean model - as in the case of other advanced OECD states-is challenged from within because of dualism in the labor market between core and secondary workers and other structural challenges that might endanger future welfare state expansion.

\section{EXPANDING WELFARE POLICIES IN DEVELOPING COUNTRIES}

Most developing countries are not yet in a position to learn from the experience of the Korean developmental state. Either they have a history of failed efforts to construct a developmental state, as is the case for some Arab, Latin American, and African countries, or they have never been in a position to engage in this effort in the first place. Thus, at present most developing countries that are classified by the World Bank as low-income or lower-middle-income countries do not display the characteristics of developmental statehood in either the authoritarian (selective) or the democratic (inclusive) variety. Instead, these countries suffer from weak or even failed statehood, and the capability of the groups controlling the state to advance policies combining economic growth and social development is weak or nonexistent.

Figure 1 describes various routes from developmental statehood to mature welfare statehood. Most developing countries would not even fit on this continuum, as they either have not tried to construct a developmental state or have tried and failed. Most OECD countries with the exception of Chile, Mexico and Turkey—on account of their significantly lower GDP per capita in comparison with the other OECD member states-would be located on the right side of the figure, having completed the transition to a mature welfare state. Taiwan and some other advanced (city) states would also be located on the right side. The People's Republic of China, which might be considered a selective socialist developmental welfare state with an aspiration to become an inclusive socialist development welfare state, would be located in the middle of the graphic moving upward.

In order to link the previous discussion with the debate about future advances in the role of the state in development, it is therefore necessary to stress two themes: (1) analytical continuity in efforts to define how state agency can advance developmental and welfare objectives, and (2) new ideas that might help to overcome previous shortcomings of state activity in the development process.

In considering the moment of continuity, it is important to stress the analytical strength of certain versions of modernization theory. Here, the analytical point of 
Figure 1. Possible Transitions from Developmental Statehood to M ature W elfare Statehood

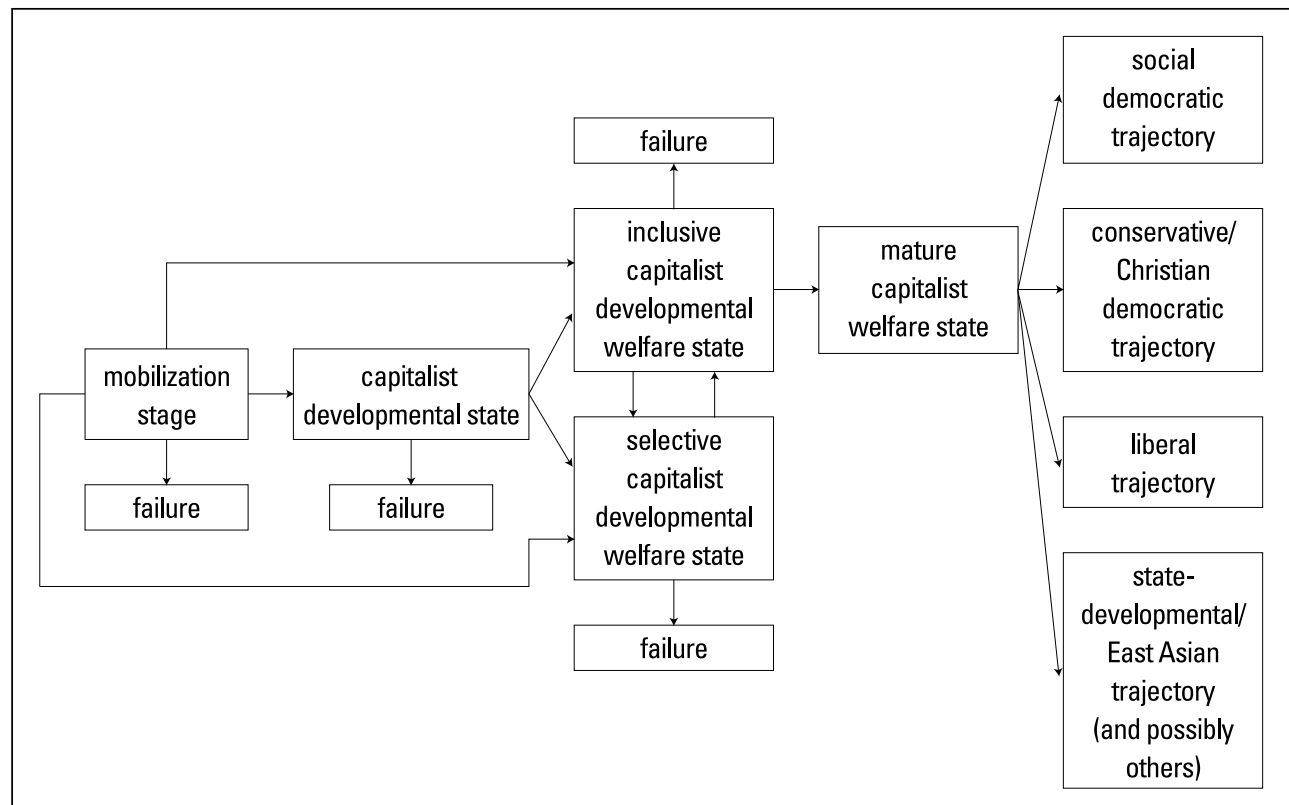

Note: The mobilization stage stands for political efforts to make the state assume a strategic and effective role in economic development. The arrows should be considered to indicate a general tendency of development rather than unidirectional change.

departure is that any kind of formalized welfare provision is closely related to GDP per capita levels. These approaches have suggested that once a certain GDP level has been exceeded, expansions of welfare statehood (such as the extension of social insurance programs from core state employees and core workers to the rest of the population) should be expected, while informal labor markets and lack of coverage should decline or disappear altogether.

After World War II, these approaches influenced development policy by focusing on underlying similarities in the trajectory of global welfare policy and the history of statehood. This might still be useful in order to critically scrutinize assumptions of welfare regime theories and models that focus on particular cultural or other "unique" variables to explain policy outcomes. However, the analytical strength of modernization theory is directly linked with a parallel weakness: such analytical accounts tend to be rather deterministic, and at times question the ability of actors to intervene in the process of policy-making and change predetermined outcomes.

More recent analyses have challenged the idea of a direct link between GDP per capita and development and welfare policies. The most basic challenge concerned the 
importance of political opportunity structures and political mobilization. For example, the nature of political coalitions and political settlements with domestic actors might be more important than economic indicators in determining states' political and resource mobilization capacities and ability to act effectively (UNRISD 2010, 258-59).

A second criticism stressed the need to reconsider the sequencing of social policy development, and to provide basic social security without further delay in order to "stabilize societies first before stabilizing economies" (Michael Cichon, quoted in ILO 2007a). It was also suggested that, at any given level of GDP, states did enjoy considerable room for maneuver in choosing their levels of social expenditure (ILO 2007b, 3).

A third line of inquiry suggested expanding the focus beyond economic development levels and toward alternative pathways of welfare provision. This concerned "social protection by other means," such as the potentially welfare-enhancing outcomes of land reforms, agricultural and consumption subsidies, marketing boards, and productivity gains through social investment (UNRISD 2010, 266; Mishra 2004).

Finally, it has been argued that mutual respect between state officials and citizens is required to make welfare policies work. Such policies need to take account of citizens' aspirations and expectations because "people simply do not care for the society . . . if the society does not care for them and/or the economy does not provide them security and an ever-lasting opportunity to increase the value of their human, social and cultural resources" (Aspalter 2007, 7).

In order to further analyze competing approaches to welfare policy in developing countries, the remainder of this article will briefly engage with two more debates. The first concerns proposals that were made in the context of advocacy for global basic social security, most notably the Global Extension of Social Security, initiated by the International Labour Organization, which was expanded in 2009 to include the UNbacked Universal Social Protection Floor initiative in reaction to the global economic crisis (GESS 2010). The second debate concerns the potential of transformative social policies in developing countries and of universal social protection as advanced by a UN-associated research body (UNRISD 2010).

\section{Basic Social Security}

The policy focus on basic social security in developing countries is by no means new. The starting point was the observation that welfare provisions under earlier colonial structures had been limited to some civil servants and core workers in sectors of employment that were important for the colonial power. These limits continued in the post-colonial era: in many cases, formal social provisions, such as social insurance systems, remained limited to a "state class." Subsequently, there was no tendency to 
expand welfare provisions from the small sector of formal employment to the larger sector of informal employment. In a typical early statement of the problem, a shift to basic social security was advised to provide "satisfaction of an absolute level of basic needs . . . [and] to concentrate development measures more directly on the poorest groups of the population" (ILO 1976, 31).

More recent advocates of basic social security have suggested that such policies would have the advantage of being realistic in terms of required funding. Thus, it was asserted that developing countries would be able to phase in basic universal social protection packages consisting of old age and disability pensions, child benefits, and access to essential health care. Such policies would require relatively modest funding in terms of share of GDP, although some resource transfers from richer donor countries might be required. ${ }^{12}$ The level of administrative costs for different components of basic social security remains contested, however. It has been stressed that such policies would still have to be advanced as part of a broader social reform effort (Casey and McKinnon 2009, 92-94).

A more modest version of basic social security consists of targeted programs based on mechanisms such as means-testing or behavioral conditions for cash transfers. Targeting and direct resource transfer to the poor is held to be difficult to enforce at the level of program delivery, however, due to many developing countries' weak administrative capacities (Sumarto 2006). Moreover, many of the assertions about the potential of basic social security to positively affect larger social development objectivessuch as higher labor productivity and higher lifetime earnings-depend on the scope and design of adopted policies.

Thus, conflict between basic and comprehensive approaches to social policies is to some extent inevitable, and it would be wrong to construct an absolute contradiction between basic and comprehensive approaches (Aspalter 2007, 5). On the one hand, shortcomings in welfare universalism must be expected in the case of regressive universalism, in which flat-rate subsidies are disproportionally accessed by better-off members of society. On the other hand, social safety nets that target only the poor leave core sections of society uncovered and therefore would be easy to retrench. In addition, targeted policies produce highly fragmented systems that are costly to administer, and tend to limit attention to statistical poverty at the individual level (ESCAP

12. A recent costing exercise for a group of low- and middle-income African and Asian countries suggested that basic health coverage would be the most costly component. In order to introduce basic social security in the near future, a combination of changes in domestic resource allocation, raising of new resources through insurance schemes, and assistance from international donors was considered necessary (Hagemejer and Behrendt 2009). 
2010, para. 25 and 28).

However, most critics of basic social security agendas raise concerns that go beyond issues of management. They suggest that these policies are often too limited or act as the social side payment within a development framework that is still fundamentally neoliberal (Adesina 2010, 8). In addition, such policies might be inappropriate in countries in which poverty is widespread; it could also undermine preexisting notions of solidarity in societies that stress equal access to resources. Most importantly, such policies have been criticized for dealing with symptoms rather than the underlying reasons for underdevelopment: "The factors that may eventually reduce poverty are not those that address its proximate causes, nor are they the most obvious ones like targeting the poor" (UNRISD 2006, 2).

\section{Universal Social Protection}

In order to overcome the shortcomings of the basic social security approach and to advance a more comprehensive paradigm, one needs to return to developmental welfare statehood. In addition, the notion of universal social protection, as recently advanced by a UN-associated research institute, must be considered (UNRISD 2010). Both concepts reaffirm that economic and social development must be analyzed together, and there is broad consensus about this fundamental point. For example, it has been stressed that "developmental linkages" between welfare and economic policies are required in order to transcend "mono-tasking" and advance "transformative social policies" (Cook 2010; Adesina 2010). However, it often appears difficult to examine what level of policy-making is referred to beyond the normative orientation in favor of linking economic and social development.

There are at least three ways to clarify the ability of social policies to act in a transformative manner. First, one can collect experiences with successful policy instruments that, on their own, link economic growth and social development objectives. For example, agricultural input subsidy programs might be examples of efforts to combine social investment policies and strategic economic policy. The same might apply for many of the policies that have been referred to in the literature as "social policy by other means."

However, collecting experiences of policy success is not sufficient, since the advocates of universal and transformative social policies put heavy stress on the fact that there is no single model to follow and that heterodox policies should be applied to reflect differences between countries. Moreover, many development policies are likely to have a limited time horizon before they require change or replacement by new policies. Thus, looking at "best practice" and "policy learning" might be less promising than expected. The experience of the East Asian countries highlights that even the 
most similar countries_-Korea and Taiwan_-did initially choose different economic and welfare policies. In fact, in both cases, democratization and political mobilization were more significant factors to explain the subsequent expansion to inclusive welfare statehood than previous economic strategies or features of developmental statehood.

Second, in order to advance democratic and inclusive developmental welfare states, the scope of analytical effort must be broadened beyond the level of policy instruments. Rather than looking at the micro level, as in the case of many basic social security approaches, the form of statehood and the nature of political mobilizations within the political system should be considered, as they are the decisive factors that shape the subsequent framework of policy-making. Thus, state building for development concerns issues such as resource mobilization and fiscal capacity that, in turn, shape policy choices on welfare.

While different resources might be available in principle, it has been stressed that progressive taxation (including public social insurance based on progressive payroll taxes) is a more stable and reliable policy tool to mobilize resources for development than other sources such as aid, remittances, or rents deriving from natural resources (UNRISD 2010, 212-14). For example, the level of progressive direct taxation in East Asian countries is at present three or four times higher than in Latin America, and this is one of the crucial factors explaining higher levels of income equality and welfare in East Asia, pointing to taxation as an "intrinsic dimension of the state" (UNRISD 2010, $215,218)$. In addition, high levels of investment in human capital development in East Asia (which are absent in Latin America) might be explained by the previous existence of higher degrees of income equality.

Finally, some of these observations might lack relevance for the least developed countries, in which any kind of formal welfare effort would be a step forward. Yet the inclusive developmental welfare states in East Asia developed only over time, a process that was due to political agency and mobilization, not predetermined by modernization. Thus, rather than constructing an absolute contradiction between basic and universal social protection, it might be better to identify those social policies that are achievable at present—such as universal minimum safety nets — and to link targeted protective intervention with efforts to move toward progressive universalism at a later point (Cook 2009, 13, 26).

As long as the aspiration to universalism informs policy-making, resource shortages and limits in weaker states' capabilities might be overcome in an incremental manner. Conversely, as long as state structures remain authoritarian and biased against the expansion of welfare policies toward universalism - as in the case of Singapore and Hong Kong-even comparatively high levels of GDP per capita might not result in inclusive welfare policies. 


\section{CONCLUSION}

This article has analyzed the concepts of developmental statehood and developmental welfare statehood. The main focus has been on clarifying the analytical terminology. In order to summarize the findings, three main themes might be extracted from the previous discussion.

The first theme concerns the developmental state and suggests that such states' traditional policies to advance in the international division of labor, namely import substitution and export promotion, remain fundamentally valid. These two objectives must be understood as complementary and mutually supportive. On the other hand, the external conditions under which developmental states find themselves and must act are equally important and subject to permanent change. States need to reinvent their strategies by applying a mix of selective incentives in accordance with national conditions while not accepting one-size-fits-all advice from international organizations.

What remains crucial for any kind of developmental state is that "reciprocal control mechanisms" between state actors, the private sector, and civil society must be promoted to avoid state capture by private interests (Amsden 2001). Here, East Asian experiences with selective incentives and performance targets for domestic producers, and a combination of what has been referred to as "market leadership" and "market followership" in terms of the interaction between state officials and the private sector, might still be relevant (Wade 2010).

Crucially, the developmental state must reject advice to accept maximum openness to trade and investment: such trade liberalization policies, referred to as leveling the playing field, might hurt the advancement of countries if foreign direct investment results in enclaves that damage domestic producers and fail to deliver technology transfer or improved national research and innovation capacities.

Second, in the twenty-first century, the agenda of developmental states must be expanded to developmental welfare statehood. It can no longer be argued that there is a fundamental contradiction between developmental states and welfare policies, as suggested in early versions of the concept (Johnson 1982, 1999). Indeed, the research presented here has stressed that developmental states, in order to be successful, require some selective welfare policies from the very beginning. The cases of Korea and Taiwan suggest, however, that early stages leave scope for indirect welfare-enhancing policies such as land reform, the conscious decision to limit degrees of wage inequality, and the creation of economic, political, and social coalitions to stabilize and enhance state capabilities (UNRISD 2010, 259-69).

Nevertheless, the concept of the developmental welfare state remains ambiguous. It is not clear, for example, whether or not inclusive developmental welfare statehood 
is an option for countries at a comparatively low level of socioeconomic development, or at what point of economic advancement transition to such a model becomes feasible. Conversely, do states at a more advanced economic and social stage grow out of the model by shifting to "normal" mature models of statehood, or do they maintain features of developmental statehood even when reaching the level of the advanced OECD countries such as Korea?

Another related problem is that the advocates of developmental welfare statehood tend to describe connections between economic development and social progress in a rather broad and unspecific manner. Thus, there is a shortage of specification on how the economic and social policies of the developmental state interact at different stages, and to what extent political mobilization can ease the transition to welfare universalism.

Third, it has been argued that the overarching need of policy-making in the twentyfirst century is to provide a "capability enhancing state" based on "investment in human capital and the socio-economic environment" (Evans 2010, 38, 40). The institutions of social policy must become more reflective of people's needs and aspirations and, in this sense, the connotation of the term "developmental welfare state" remains problematic. The term still implies that welfare policies are introduced from above with little concern for actual demand from below. However, the Korean case also demonstrated that co-option of civil society leaders into state bodies was one of the preconditions for the successful expansion of welfare policies after the Asian financial crisis of 1997 (Peng 2004, 408, 415).

One way of accounting for the difficult relationship between state agency and civil society in the welfare field might be to adapt the term and to speak instead of "welfare developmental states." This indicates a shift in the hierarchy from developmental to welfare objectives, thereby indicating policies that are directly capability-enhancing at the level of the individual. The welfare developmental state might be considered to engage in activities such as the efficient delivery of health and education services, provision of inexpensive public transport, and efforts to increase access to opportunities that help people to expand their skills and capabilities.

The key to economic and social growth in the twenty-first century, which certainly must be measured in terms that go beyond a narrow concern with GDP per capita, is to be found in state efforts to allow people to exercise and develop their own agency and to make a productive contribution to society. Such a policy orientation might overcome shortcomings of earlier developmental states, such as the narrow focus on economic actors, and could help to link civil society aspirations with state-provided services. It could also help to bridge the gap between demands for basic social security and the need to build up universal social protection.

Last, the explicit stress on the need to stabilize and strengthen states in the develop- 
ing world in order to increase the likelihood of development policies to be successful and to increase welfare can serve as a useful critical device against liberal accounts of development policy that tend to focus heavily on markets and nonstate actors. This is not to deny that, more often than not, past authoritarian developmental states failed to advance social development. However, in the developing world, weak statehood has been more common, and the majority of developing countries in Africa and Latin America never reached the mobilization stage from which a shift toward developmental statehood of any kind would have become possible. In conclusion, the concepts of developmental (welfare) statehood remain essential and promising aspects of the discourse on development in the twenty-first century.

\section{REFERENCES}

Adesina, J. O. 2010. Rethinking the social protection paradigm: Social policy in Africa's development. In Strategies for social protection in the global multi-crises, ed. Graduate School of Public Administration, 7-32. Seoul: Graduate School of Public Administration.

Amsden, A. H. 2001. The Rise of "The Rest": Challenges to the West from LateIndustrializing Economies. Oxford: Oxford University Press.

Aspalter, C. 2006. The East Asian welfare model. International Journal of Social Welfare 16: 290-301.

2007. Towards a human capital welfare state? In search of win-win solutions. Journal of Societal and Social Policy 6 (1): 1-46.

Blyth, M. 2002. Great Transformations: Economic Ideas and Institutional Change in the Twentieth Century. Cambridge, UK: Cambridge University Press.

Brütt, C. 2010. Workfare als Soziales. Zur Arbeitsmarkt- und Sozialpolitik der Großen Koalition. In Die Große Koalition: Regierung-Politik-Parteien 2005-2009, ed. S. Bukow and W. Seemann, 123-41. Wiesbaden: VS Verlag.

Casey, B. H., and R. McKinnon. 2009. Social pensions and policy learning: The case of southern Africa. International Social Security Review 62 (4): 81-102.

Chang, D.-o. 2009. Capitalist development in Korea: Labour, capital and the myth of the developmental state. London: Routledge.

Chang, H.-J. 2009. Industrial policy: Can we go beyond an unproductive confrontation? Paper presented at the Annual World Bank Conference on Development Economics, Seoul.

Cook, S. 2009. Social protection in East and South East Asia: A regional review. http://www.socialprotectionasia.org/pdf/Sarah-Cook-SPA-WP02.pdf. 
2010. Social protection and inclusive growth: The critical like between protection and production. Memo for Asian Development Bank Annual Meeting. Tashkent, May 4.

Cumings, B. 2005. State building in Korea: Continuity and crisis. In States and development: Historical antecedents of stagnation and advance, ed. M. Lange and D. Rueschemeyer, 211-35. Houndmills, UK: Palgrave.

Cypher, J. M., and J. L. Dietz. 2009. The process of economic development. 3rd ed. Abingdon, UK: Routledge.

Dore, R. 2000. Stock market capitalism: Welfare capitalism. Japan and Germany versus the Anglo-Saxons. Oxford: Oxford University Press.

. 2007. Shareholder capitalism comes to Japan. Working Paper in Technology Governance and Economic Dynamics 11, The Other Canon Foundation, Norway, and Tallinn University of Technology, Tallinn. http://hum.ttu.ee/tg.

Eckert, C. J. 1991. Offspring of empire: The Koch'ang Kims and the colonial origins of Korean capitalism 1876-1945. Seattle: University of Washington Press.

ESCAP (United Nations Economic and Social Council for Asia and the Pacific). 2010. Regional trends and emerging issues in the field of social development, particularly social protection for the most vulnerable social groups. E/ESCAP/ $\mathrm{CSD}(2) / 1$. Bangkok: ESCAP.

Esping-Anderson, G. 1990. The three worlds of welfare capitalism. Princeton, NJ: Princeton University Press.

Evans, P. B. 2010. Constructing the 21st century developmental state: Potentialities and pitfalls. In Constructing a democratic developmental state in South Africa: Potentials and challenges, ed. O. Edigheji, 37-58. Cape Town: HSRC Press.

GESS (Global Extension of Social Security). 2010. Basic social protection package. http://www.socialprotectionfloor.org/gimi/gess/ShowTheme.do?tid=12.

Hagemejer, K., and C. Behrendt. 2009. Can low-income countries afford basic social security? In Promoting pro-poor growth: Social protection, ed. Organisation for Economic Co-operation and Development, 89-109. Paris: OECD.

Hamilton, C. 1986. Capitalist industrialization in Korea. Boulder, CO: Westview Press.

Hamilton, G. G., and K. Cheng-Shu. 2008. Taiwan's industrialisation: The rise of a demand-responsive economy. In Social transformations in Chinese societies: Special focus Chinese capitalisms, vol. 3, ed. C. Kwok-bun, C. Tak-sing and A. $\mathrm{S}$. Ku, 95-131. Leiden: Brill.

Holliday, I. 2000. Productivist welfare capitalism: Social policy in East Asia. Political Studies 48 (4): 706-23.

Hwang, S.-J. 1994. Zur kapitalistischen Entwicklung und Kapitalismus-Debatte in 
Südkorea. Frankfurt am Main: Peter Lang.

ILO (International Labour Organization). 1976. Employment growth and basic needs: A one-world problem. Geneva: ILO.

. 2007a. World social security forum-building a "social security floor" worldwide where growth can meet equity. http://www.ilo.org/global/About_ the_ILO/Media_and_public_information/Feature_stories/lang-en/WCMS_ 084138/index.htm.

2007b. Issue paper for session 4: Social security policies for social cohesion and economic development. http://www.ilo.org/global/What_we_do/ Events/Symposiaseminarsandworkshops/lang—en/WCMS_084240/index.htm.

Johnson, C. 1982. MITI and the Japanese Miracle: The Growth of Industrial Policy, 1925-1975. Stanford, Cal.: Stanford University Press.

1999. The developmental state: Odyssey of a concept. In The developmental state, ed. M. Woo-Cumings, 32-60. Ithaca, NY: Cornell University Press.

Kasza, G. J. 2002. The illusion of welfare "regimes." Journal of Social Policy 31 (2): 271-87.

2006. One world of welfare: Japan in comparative perspective. Ithaca, NY: Cornell University Press.

Kiely, R. 2007. Poverty reduction through liberalisation? Neoliberalism and the myth of global convergence. Review of International Studies 33 (4): 415-34.

Kim, E. M. 1993. Contradictions and limits of a developmental state: With illustrations from the South Korean case. Social Problems 40 (2): 228-49.

Kim, Y.-M. 2008. Beyond East Asian welfare productivism in South Korea. Policy and Politics 36 (1): 109-125.

Kim, B.-s., J.-u. Moon, and S. Lim. 2009. IT industry development and policy tools in Korea. In Global and national strategy for poverty reduction, ed. Graduate School of Public Administration and United Nations Research Institute for Social Development, 15-35. Seoul: Graduate School of Public Administration.

Kwon, H.-j. 2005. Transforming the developmental welfare state in East Asia. Development and Change 36 (3): 477-97.

Kwon, H.-j., T. Mkandawire, and J. Palme. 2009. Introduction: Social policy and economic development in late industrializers. International Journal of Social Welfare 18:1-11.

Kwon, H.-j., G. Dong, and H.-G. Moon. 2010. The future challenges of the developmental welfare state: The case of Korea. http://www.social-policy.org.uk/lincoln/ Kwon.pdf.

Lee, Y.-J., and Y.-w. Ku. 2007. East Asian welfare regimes: Testing the hypothesis of the developmental state. Social Policy and Administration 41 (2): 197-212. 
Mishra, R. 2004. Social protection by other means: Can it survive globalisation? In $A$ handbook of comparative social policy, ed. P. Kennett, 68-88. Cheltenham, UK: Edward Elgar.

MSF (Ministry of Strategy and Finance). 2001. Corporate restructuring promotion law legislated. http://english.mosf.go.kr/news/pressrelease_view.php?sect= news_press\&sn $=1483$.

NPF (National Policy Foundation). 2009. Establishment of the pension system in Taiwan. http://www.npf.org.tw/post/3/5577.

Park, C.-u., and D. Jung. 2009. Making sense of the Asian welfare regimes with the western typology. Korean Journal of Sociology 43 (3): 57-85.

Parsons, A. D. 2008. World Bank poverty figures: What do they mean? http://www. stwr.org/globalization/world-bank-poverty-figures-what-do-they-mean.html.

Peng, I. 2004. Postindustrial pressures, political regime shifts, and social policy reform in Japan and South Korea. Journal of East Asian Studies 4 (3): 389-425.

Polanyi, K. 1967 [1944]. The great transformation: The political and economic origins of our time. Boston: Beacon Press.

Riesco, M., and S. Draibe. 2009. Is global welfare and a global New Deal possible? http://www.unrisd.org/unrisd/website/events.nsf/ee1a3b60f271933180256b640 03a0d88/f6b7601e756cead1c12576a20057505c/\$FILE/RiescoDraibe.pdf.

Shin, J.-S., and H.-J. Chang. 2003. Restructuring Korea Inc. London: Routledge.

Sumarto, S. 2006. Social safety nets: Indonesia. Policy Brief 5, Interregional Inequality Facility, Overseas Development Institute, London.

Timmer, M., and B. van Ark. 2000. Capital formation and foreign direct investment in Korea and Taiwan: Coping with diminishing returns? http://www.rug.nl/staff/ h.h.van.ark/FDIpap.pdf.

UNRISD (United Nations Research Institute for Social Development). 2006. Transformative social policy: Lessons from UNRISD research. Research and Policy Brief 5, UNRISD, Geneva.

2010. Combating poverty and inequality: Structural change, social policy and politics. Geneva: UNRISD.

Valli, V. 2010. The economic ascent of a technological power: South Korea. Working Paper 14/2010, Department of Economics "S. Cognetti de Martiis," Universitá di Torino.

Verdery, K. 1996. What was socialism, and what comes next? Princeton, NJ: Princeton University Press.

Wade, R. 1990. Governing the market: Economic theory and the role of government in East Asian industrialization. Princeton, NJ: Princeton University Press. 2010. After the crisis: Industrial policy and the developmental state in low- 
income countries. Global Policy 1 (2): 150-61.

Wood, G., and I. Gough. 2006. A comparative welfare regime approach to global social policy. World Development 34 (10): 1696-1712.

Wu, Y.-S. 2007. Taiwan's developmental state: After the economic and political turmoil. Asian Survey, 47 (6): 977-1001.

Yusuf, S. 2009. Freeing the world of poverty. In Development economics through the decades: A critical look at 30 years of the World Development Report, ed. S. Yusuf with A. Deaton, K. Dervis, W. Easterley, T. Ito, and J. E. Stieglitz, 19-49. Washington, DC: World Bank. 